\title{
LA TIERRA COMO ÉTICA Y ESTÉTICA CONTINENTAL: GÜIRALDES, RIVERA, GALLEGOS Y ANDRADE
}

\author{
Jesús Ernesto Ortiz Díaz
}

Las novelas que analizaremos en este ensayo -publicadas entre 1917 y 1929- marcan un regreso a la tierra que la obra de Euclides da Cunha, Alberto Rangel y Horacio Quiroga ya habían inaugurado. Las ideas presentes en los textos de dichos autores son retomadas como base de los debates y las propuestas que se plantean en Raucho (1917), La vorágine (1924), Macunaíma (1928) y Doña Bárbara (1929) con respecto a la identidad literaria y nacional en el marco de la discusión de la antinomia entre la civilización y la barbarie en América Latina. En espíritu, estos textos se apegan a lo que Rodó y Martí proponían en Ariel y Nuestra América, respectivamente, al materializar el pensar es servir y apoyar la ficción literaria en los andamios de un pensamiento abocado a proponer soluciones a los grandes problemas nacionales y zanjar, de paso, el debate de la identidad literaria en términos telúricos y nacionalistas: "la naturaleza americana aparece como un espacio en blanco no codificado que ofrece al escritor [...] todo un nuevo mundo por explotar y que coincide, además, con la renovada vocación nacionalista que se produce en esa misma época" (PERA, 1997, p. 182).

La articulación de este modelo literario -manifiesto en las novelas que se analizan en este ensayo- coincidió en el tiempo con la instauración de regímenes totalitarios en casi todos los países de origen de los textos aludidos. Ello convirtió tanto a sus autores como a los textos per se en una 
encarnación de los estadistas naturales y de esa literatura comprometida con la nación a la que apelaron, en su momento, Martí y Rodó.

Raucho (1917) figura entre los primeros textos escritos por Ricardo Güiraldes; de hecho, fue la primera novela que publicó. Sin embargo, en ella, lejos de advertirse trazos estilísticos inusitados al interior de lo que sería su obra o vislumbrarse un largo camino hacia su producción de madurez como lo es Don Segundo Sombra (1927), se aprecia ya una sólida consistencia en lo referente a la posición de Güiraldes frente a las cuestiones de la identidad literaria americana frente al influjo de las escuelas europeas. Si como afirma Ángel Rama (1982),

\begin{abstract}
un novelista no se parece nada a Adán; no es aquél que, como imaginó el poeta romántico despertó y fue nombrando las cosas, haciendo palabras vírgenes para las cosas vírgenes. El novelista existe dentro de una literatura; si hablamos, en abstracto, diríamos que nace dentro de ella, en ella se forma y desarrolla, con ella y contra ella hace su creación. Y por lo mismo, es heredero de una tradición y creador de tradiciones (p. 49),
\end{abstract}

es ineludible, pues, mencionar el diálogo que se establece entre la novela de Güiraldes y Sin rumbo (1885) del también argentino Eugenio Cambaceres.

El ennui y la esterilidad con que la juventud es retratada por Cambaceres en esa obra, los contesta Güiraldes en Raucho a través de la historia de otro personaje, cuyo perfil no sólo es un guiño al Andrés de Sin rumbo -también es joven y descendiente de terratenientes-, sino, sobre todo, cuya trayectoria de vida es utilizada para desdecir las premisas pesimistas del determinismo europeo que encumbraba el texto de Cambaceres. Echando mano de una estructura que recuerda a aquélla de las novelas de tesis, Güiraldes escribe una historia que funciona al mismo tiempo como una bildungsroman a través de la cual el lector acompaña al protagonista-Raucho- por una serie de eventos que definen su relación con la tierra y, por ende, con la patria. ${ }^{1}$ Al final de la novela,

${ }^{1}$ En De pronto, el campo, Graciela Montaldo (1993) reconstruye el contexto histórico y las ideas de la época en lo referente a la relación entre la argentinidad, la ciudadanía y el espacio rural: "La década del diez, auspiciada por los festejos de los centenarios, es testigo de la canonización del gaucho como figura que, perteneciendo de lleno al pasado, carga sobre sí el peso de la tradición argentina y es él mismo esa tradición; el campo es su marco. Al menos esto es así entre los letrados que han sido capaces de generar versiones acerca de la historia cultural argentina en el momento no sólo de la celebración de las fiestas, sino de la conmoción que producía en el país el progresivo asentamiento de la inmigración" (p. 87). 
tras el interludio europeo, Raucho no sólo alcanza su madurez psicológica y moral al tiempo que recobra su plenitud física, sino que se convierte en un ciudadano ejemplar al asumir la responsabilidad del progreso de su patria que es, a la vez, el suyo propio. Propongo, pues, leer Raucho como un tratado didáctico de ciudadanía para esa juventud que era el motivo de preocupación de Martí y Rodó; ${ }^{2}$ es decir, una apuesta que difundiese entre los jóvenes la viabilidad de una patria americana fundada en una moral que había de hallar su inspiración en la fortaleza y sinceridad de la naturaleza americana en contraposición a la decadencia y encanijamiento que se percibían en la sociedad europea de la época.

La naturaleza en Raucho trasciende la mera condición de ornato que provee de tintes costumbristas la narración de la vida de Raucho Galván. Es, desde el primer momento, un elemento protagónico en la novela que supera el alcance de la falacia patética romántica y la mera personificación. En Raucho como en la narrativa de Quiroga la naturaleza -representada por el espacio rural o la pampa- establece una lógica de contrapunto frente a la civilización -bajo la forma de la gran urbe: Buenos Aires o París. Sin embargo, a diferencia de lo que acontece en la obra del escritor uruguayo, para quien la naturaleza existe en sí y para sí, ajena, en consecuencia, a los avatares de la civilización y cuya lógica parece cruel y caótica ante los ojos de los seres humanos, en Raucho, Güiraldes opera una domesticación de la naturaleza en el sentido más etimológico de la palabra: la hace el domus por excelencia del hombre; la convierte en hogar y en espacio maternal relacionado con el origen y la identidad nacional. La selva de Quiroga cede, pues, su lugar a la pampa de las estancias donde el hombre no está a merced de la naturaleza, sino la naturaleza es doblegada por la voluntad del hombre. En Raucho no hay como en Quiroga una inversión total de la jerarquía al interior de la dicotomía civilización y barbarie; sino que, en su lugar, Güiraldes, siguiendo los pasos de Euclides y Rangel, apuesta por una civilización alimentada y legitimada por y desde las propias fuentes telúricas frente a los impostamientos de importación.

${ }^{2}$ Cristóbal Pera comenta con respecto a la función didáctica en esta novela que: "Raucho podría considerarse una novela didáctica. El título de los capítulos es, de por sí, ilustrativo: 'Infancia,, 'Colegio', ‘Trabajo, 'Hastío, 'París', 'Niña', 'Abandono', 'Solución'. La solución, en este caso, implica la superación de la dicotomía que consume al protagonista entre su tierra natal americana, origen de su energía natural, y la imagen textual de una ciudad, París, tras cuyo contacto aparece la enfermedad (cáncer) que absorbe toda su vitalidad" (1997, p. 182). 
Aunque no terminaría de gestarse sino hasta diez años después con la publicación de Don Segundo Sombra (1927), ya desde Raucho, Güiraldes otorga a la naturaleza el rol de magistra vitae. No lo hace, sin embargo, a través de una figura arquetípica de la pampa que encarnase la sabiduría de la naturaleza (como lo es Don Segundo que ya aparece como personaje en esta novela). En su lugar, en Raucho la naturaleza se vale, sí, de la seducción que provoca en el protagonista la vida de la tropa de gauchos que trabajan en la estancia pero, sobre todo, del efecto que la experiencia de su presencia o ausencia tiene sobre el mismo. En otras palabras, si en Don Segundo Sombra, Güiraldes habría de echar mano de una materialización del espíritu de la pampa para derivar toda una relación de paternidad encaminada a la enseñanza, en Raucho, el autor se sirve del determinismo en el que se apoyaban textos como Sin rumbo para dinamitar dicho modelo y, de paso, subrayar el efecto favorable del medio natural en un joven que representa, por metonimia, a todos los jóvenes de la Argentina.

En Raucho, como luego habría de repetirse en Don Segundo Sombra, asistimos a un parto. El parto a la ciudadanía del protagonista gracias al influjo de la naturaleza. Narrada de manera lineal, la historia de Raucho Galván inicia con la llegada de éste al espacio rural. Tras la muerte prematura de su madre, don Leandro -su padre- se traslada con Raucho y sus hermanos a la estancia que poseían en el interior para que sus hijos pudiesen “¡vivir, vivir en la gran alma serena de la tierra!” (GÜIRALDES, 1968, p. 7). Desdeel inicio de la novela se establece una distinción maniquea entre la esfera del campo y la de la ciudad donde la última representa la deformación de los ideales de los que es depositaria la vida rural. Esta distinción parte y se afianza desde el plano estético del texto donde la figuración de la ciudad es una materialización de la Babel deshumanizada que Rubén Darío aludiera en Canto a la Argentina (1910) para referirse a Nueva York, la que Cambaceres reprodujese en En la sangre al describir Buenos Aires (1887) o, bien, la imagen del Río de Janeiro del que Aluísio Azevedo da cuenta en O Cortiço (1890).

Junto al desorden y hacinamiento que caracterizan la Buenos Aires descrita por Güiraldes está la constante referencia al ruido que parece ser la dominante en el ambiente citadino. En continuo contraste, está el campo del alma serena, donde el gauchaje y "el personal formaba una especie de familia" (GÜIRALDES, 1968, p. 10) a la que Raucho se integra y, donde, según don Leandro, "los chicos crecerían como plantas" (GÜIRALDES, 
1968, p. 14). El campo y en particular la vida alrededor de la estancia constituyen en Raucho el dominio de la virilidad y la pureza asediadas de manera constante por los artificios de la civilización que lo hacen siempre de mano de una figura femenina que compite y, a la vez, contrasta con la naturaleza. ${ }^{3}$

La primera de estas acechanzas tiene lugar durante la infancia de Raucho bajo la forma de su institutriz alemana. Extranjera como solían serlo entonces las mujeres que educaban a los hijos de la oligarquía latinoamericana, la mujer que se encarga de introducir a Raucho y sus hermanos en la civilización europea desempeña su labor -irónicamentedesde la pampa donde sus pupilos experimentan un desfase entre el universo del saber europeo que aprendían a través de los libros y el mundo del interior rural. Así, frente a la atracción hacia lo europeo que la institutriz buscaba despertar en los niños a través de fábulas y cuentos de hadas triunfa el universo de los cuentos "de aparecidos" del gauchaje y su código de la utilización a ultranza de la fuerza. Raucho desdeña, pues, en sus juegos de niño la tradición libresca europea y se inclina por la circunstancia real de la estancia.

No obstante, cuando, en momentos, la balanza se inclina hacia el lado de la fantasía siempre es por mediación de un libro cuya lectura lejos de tener efectos beneficiosos provoca en él un desconcierto que lo pierde en las ensoñaciones y lo llevan, por ende, a la suspensión.

En oposición a ese efecto narcótico de los libros europeos -que recuerda los alegatos de Martí y Rodó- se encuentra la vida en la naturaleza al lado de los gauchos a la que Raucho decide regresar después de terminar sus estudios en la capital de la provincia pues, según se detalla en la novela, "el gran deseo de vida libre, allá en la estancia, le aclaraba el alma con un renacer viril y puro" (GÜIRALDES, 1968, p. 35). Su paso por la ciudad, a pesar de ser bastante breve en términos de las páginas que Güiraldes le dedica a la narración de dicha temporada, siembra un precedente fundamental para comprender los posteriores avatares que enfrentaría el protagonista en Buenos Aires y, luego, en París. Es en esa primera experiencia en el espacio urbano que Raucho entra en contacto

3 French aclara esta oposición estética: "for the regionalists, however, taking part in the Oedipal struggles among literary generations meant self-consciously differentiating themselves from the Francophile modernistas, and invocations of British culture became a way to signal their distance from a movement they frequently represented as 'decadent' and 'effeminate"' (2005, p. 30). 
con las mujeres teniendo como marco el mundo de la prostitución. Su primeros lances amorosos ocurren al lado de una mujer extranjera una española llamada Emilia- que sobresale entre un ejército de otras prostitutas inmigrantes ${ }^{4}$ que se congregan alrededor de un salón descrito en la más pura tradición naturalista.

El prostíbulo es un microcosmos que expresa con justedad la visión de la ciudad presente en Raucho. La atmósfera enrarecida y la atrofia moral y física de los hombres en la urbe se convierten en un leitmotif que permite, páginas más adelante, la descripción de Buenos Aires y París y su efecto pernicioso sobre Raucho. Así, pues, la segunda acechanza o avance de la civilización a través del cuerpo de la mujer acontece por intermediación de las prostitutas con quienes Raucho entabla relaciones cuyo grado de dependencia irá en aumento hasta orillarlo a una vida como la de sus últimos días en París donde existía "sin horizontes, sin salidas, como un lodazal adherente” (GÜIRALDES, 1968, p. 108).

Antes de su residencia en Buenos Aires y, posteriormente, en París, Raucho decide habitar una temporada en la estancia, luego de su regreso de la capital de la provincia donde había terminado sus estudios y cerraba -según la voz narradora- "el paréntesis de una vida artificiosa" (GÜIRALDES, 1968, p. 29). Su "ilusión de salir de preso" (GÜIRALDES, 1968, p. 29) del espacio urbano se ve correspondida en el campo al serle posible la adopción de un modo de vida que había romantizado durante su niñez, pero al que había conocido también de cerca. A su llegada al campo, atestigua la sustitución del calendario civil por el de las estaciones y labores a las que se abocaba el gauchaje. Raucho, "ya un hombre en posesión de todos sus vigores corporales" (GÜIRALDES, 1968, p. 38) y "sediento de emplearse en las lindezas del macho" (GÜIRALDES, 1968, p. 29) se une a la tropa de gauchos buscando "como ellos, someter las

${ }^{4}$ La amenaza que estas prostitutas representan para la integridad moral de Raucho se magnifica si consideramos su condición de extranjeras pues, como afirma Montaldo, la inmigración fue una de las razones que propiciaron la eclosión del ruralismo en la literatura argentina de finales del siglo XIX y las primeras décadas del XX: "El campo, la tradición rural, pasó a ocupar los primeros planos de una escena intelectual de tiempos acelerados en la que paisajes, fisonomías, rumores y costumbres variaban y al hacerlo reclamaban la modernización de la vida. Sin duda, los inmigrantes fueron uno de los grandes activadores de este rumbo de la literatura argentina [...] Los inmigrantes, en la ciudad, ayudan a dibujar la estampa de un campo argentino en la imaginación de muchos de nuestros intelectuales como lugar de origen de las diferencias" (1993, p. 22). 
dificultades más ásperas, sin temer peligros, tendido hacia el dominio absoluto sobre la bestia, el clima y las rudezas de una vida muscular" (GÜIRALDES, 1968, p. 38). No obstante, la dureza de la faena en el campo y el carácter cíclico con el que se la caracteriza empujan a Raucho a la lectura de "Lorrain, Maupassant, Verlaine, cantores y contadores de la vida parisiense en su perfume genuino de aventuras, vicios y anhelos" (GÜIRALDES, 1968, p. 51).

Es en este punto del texto cuando, nuevamente, el cuerpo de la mujer funge como vehículo a través del cual la vida urbana y la civilización confabulan para alejar a Raucho de la naturaleza, espacio que la voz narradora sugiere como el único hogar posible del protagonista. Así, pues, gracias a la intermediación libresca de una París idealizada, a la que se figura como una cortesana exquisita y complaciente, Raucho intensifica sus visitas a Buenos Aires, adonde termina por mudarse antes de su viaje a esa París en que los libros lo hacían soñarse. En Buenos Aires, sin embargo, sufre una transfiguración que lo convierte en uno de los personajes de las novelas europeas que leía con vehemencia. Adquiere el mal del siglo -el ennui- y, con ello, la suspensión de toda voluntad: en la novela se habla de "modorra lasciva", de "embrutecimiento", de "abulia", de "monotonía" para describir el estado de ánimo cuyo modelo encontraba Raucho en los protagonistas de los libros que se procuraba.

Si bien los libros de fantasía a los que la institutriz alemana aproximó a Raucho, durante su niñez, no había logrado separarlo de la esfera de lo real gracias al contacto vigoroso con lo telúrico durante su vida en la estancia, sería muy distinto el efecto que en él ejercerían los libros europeos leídos en su juventud durante los días de hastío en el campo y, posteriormente, a lo largo de su temporada en Buenos Aires. Las lecturas no sólo lo sustraen de la realidad americana, sino que lo desrealizan convirtiéndolo en una proyección especular de las ficciones que leía. Su vida en Buenos Aires es un remedo de la vida que los protagonistas de los libros que devoraba llevaban en París: "El joven Galván vio abrirse una nueva era. No hubiese cambiado su entrada al paraíso por su ida a París, y devoró más libros y novelas, queriendo esponjarse en el ambiente soñado" (GÜIRALDES, 1968, p. 58). En Raucho, al igual, que en dichos entes literarios comienza a primar la sensibilidad sobre el músculo; avanza la feminización frente a lo que es figurado como el atrofiamiento de la virilidad por el influjo de lo femenino y, en general, por causa de las relaciones con las mujeres -todas ellas cortesanas. 
La representación de la capital francesa en la novela constituye un catálogo de los clichés asociados con la París de los modernistas hispanoamericanos y de simbolistas y parnasianos brasileños: "El amplio bulevar, encajado entre sus edificios inmóviles, miraba la gente pasar a la luz de sus vidrieras. De sus vidrieras, que son como ojos a la inversa" (GÜIRALDES, 1968, p. 76). El narrador de la novela mantiene su consistencia en lo referente a su desaire de la esfera urbana que se acentúa al dar cuenta de la vida en la ciudad par excellence de aquella época: “¡París! ¡Ciudad del vértigo en que apenas se logran momentos de concentración, entre acciones que se suceden sin intervalos!" (GÜIRALDES, 1968, p. 73). Frente al silencio armónico del espacio rural, la voz narradora figura París como un espacio caótico que dista mucho de ser la ensoñación libresca de Raucho. Así, en una escena que evoca un pasaje de De sobremesa (1896) de José Asunción Silva, Raucho sufre una alucinación donde -a semejanza de la Santa Comparsa- un grupo de mujeres parisinas, materialización de sus ensoñaciones, se presentan ante él para satisfacer sus fantasías librescas al tiempo que lo vampirizan.

Es, precisamente, una espiral de vorágines corporales la que arrebata toda agencia a Raucho y lo arrastra a la degradación moral y la ruina financiera. Su trayectoria descendente durante los años que pasa en Europa la determinan las relaciones que establece con Germaine y Nina, dos cortesanas de cuyos favores se hace Raucho intentando experimentar el París de sus libros. Es en París donde, aparentemente, parece triunfar las acechanzas de la civilización a través del cuerpo de las mujeres. La alienación que provoca en Raucho la convivencia con Nina lo hace perder su virilidad representada por la atrofia del músculo o la neutralización de su fortaleza física. Raucho, al igual que los hombres de aquella ciudad, parece contraer una enfermedad espiritual que el narrador describe como "satiriasis báquica, enervada al través de los años, por el uso de los pobres cuerpos gastados, modernizados, por el pulpo dominante del sistema nervioso, que va matando la simplicidad primaria del músculo" (GÜIRALDES, 1968, p. 8o). Así, el vigor de la juventud del protagonista, que el narrador destaca durante la estancia en el campo, desaparece ante el avance de una vejez prematura que se explica como el producto de un ejercicio excesivo de la actividad sexual aludido a través de las referencias a los sátiros y a Baco. Convertido en un apéndice de Germaine, Raucho contrae una enfermedad que refleja su apocamiento espiritual. París, la 
ciudad donde "quería vivir a todo trance, atiborrarse de sensaciones hasta la saciedad" (GÜIRALDES, 1968, p. 53) lo lleva a las puertas de la muerte.

La vocación didáctica de la novela se completa cuando Raucho articula en su pensamiento una desmitificación de la París romantizada por la intermediación de sus lecturas. La temporada europea es resignificada como un contagio canceroso posibilitado por el contacto del cuerpo femenino. Raucho accede, finalmente al aprendizaje.

Asegurado su regreso a la Argentina, luego de finiquitar su relación con Nina y su desesperada situación financiera, Raucho regresa a la vida. Valiéndose de una metáfora que restaura el vínculo del protagonista con el mundo natural, el narrador advierte que en el cuerpo de Raucho "vegetó un éxtasis de brote” (GÜIRALDES, 1968, p. 110) recordando, así, al lector el sueño de don Leandro Galván que abre la novela: el de que sus hijos crecieran como plantas tras llevarlos a vivir al campo (GÜIRALDES, 1968, p. 14).

La reincorporación de Rauchoal espacio natural americano se produce al tiempo que tienen lugar tres acontecimientos simbólicos. El primero de ellos es el abrazo entre él y un gaucho que marca su reconciliación con la vida nacional de la cual había intentado distanciarse al vivir en el ensueño parisino en Buenos Aires y en la propia París. El segundo es la sugerencia que hace el narrador del compromiso matrimonial entre Asunción y Raucho. Asunción, a quien Raucho había conocido y de quien había quedado prendido antes de su viaje a París, es la única de las mujeres en la novela cuya unión no supone el descoyuntamiento de la relación telúrica entre Raucho y el campo. Descrita, significativamente, por el narrador como una "diosa salvaje" (GÜIRALDES, 1968, p. 62) lo cual anuncia el advenimiento de figuras literarias posteriores como la doña Bárbara de Rómulo Gallegos-, Asunción es la única mujer con quien Raucho puede establecer una relación productiva: su unión no sólo implica el enraizamiento definitivo de Raucho en el campo, sino su elevación moral, como sugiere incluso el nombre de aquélla. No se la describe con los adornos y oropeles de las cortesanas citadinas, sino como una mujer cuya fisonomía nacional y estampa saludable la hacen símbolo mismo de la prodigalidad de la naturaleza americana: "de cuerpo firme y bruna de aires abiertos" (GÜIRALDES, 1968, p. 113).

La novela se cierra con el que es, a mi parecer, el más simbólico de los acontecimientos: Raucho abandonando sus atuendos europeos, recupera 
su vestimenta de gaucho -su ser verdadero, según lo sugiere el narradory afirma su pertenencia a la tierra.

Si la novela se abría con la muerte de la madre de Raucho, su cierre puede ser leído como una restitución simbólica del protagonista al vientre maternal de la naturaleza donde yace arrullado por los misterios serenos del agua. Al igual que en "Los desterrados” de Quiroga, Güiraldes desvela en Raucho, a través de una arquitectura didáctica, el sólido vínculo del hombre americano con la naturaleza, "su tierra de siempre" (GÜIRALDES, 1968, p. 115). Sin embargo, a diferencia de Quiroga, Güiraldes figura el regreso a la naturaleza como un compromiso con el desarrollo de la patria: Raucho vuelve a la pampa ya no con el desahogo de su antigua posición de terrateniente, sino dispuesto a trabajar en ella “aunque fuera de peón” (GÜIRALDES, 1968, p. 114).

El regreso a la tierra en Raucho, la finalidad didáctica del texto, así como la trayectoria a la bildungsroman que recorre el protagonista encontrarán su eco en un proyecto literario aparentemente tan disímil pero que es, en sustancia, tan afín a la novela de Güiraldes: La vorágine. Publicada en 1924, esta novela de José Eustasio Rivera dialoga con el espíritu que anima la obra de Euclides da Cunha, Alberto Rangel y del mismo Horacio Quiroga. Éste, en una carta dirigida a Rivera, elogió su novela al encontrar en ella coincidencias estilísticas y sondear en su escritura el mismo interés por el espacio natural que lo había hecho habitar en la selva Misiones.

En su complejidad formal y su exceso retórico, ${ }^{5}$ La vorágine coincide con la estética quiroguiana en su intención fotográfica de plasmar la naturaleza en su carácter hostil a través de la prosopopeya de la selva. De hecho uno de los cuentos de Quiroga -"La miel silvestre" (1911)- preludia ya la génesis de la novela de Rivera. Así, al igual que hiciera Quiroga en su relato, en La vorágine, Rivera, da cuenta de la infortunada experiencia de sujetos citadinos incautos o, incluso, ingenuos ante las leyes de la naturaleza en el espacio interior americano.

5 Cedomil Goic comenta cómo, en La vorágine, Rivera logró resolver la paradoja estética sobre la que está cimentada la novela: "[Rivera] resuelve espléndidamente, con una revelación de grotesco superior, trágico y demoníaco, las tensiones de lo real y lo misterioso, sin dejar -paradójicamente- de presentar el mundo novelístico con la aspereza aniquiladora con que el naturalismo, en general, narró los destinos caracterizados por sus errores o engaños imaginarios" (1991, p. 584). 
El texto de Rivera resignifica la ruta descabellada de su protagonista en un marco estructural que recuerda una künstlerroman. ${ }^{6}$ No obstante, a diferencia de otras künstlerromane, no se trata de una novela en la que se narre la maduración artística de un creador en una progresión convencional que parte del puñado de inquietudes de una tabula rasa. Al contrario, en La vorágine el lector atestigua ya desde un principio la crisis de la voz artística de Arturo Cova -un poeta colombiano cuyos versos patrióticos lo han consagrado y le han dado un gran renombre, según se alude a lo largo del texto- que, en un proceso discontinuo y apremiado por las circunstancias, va desaprendiendo y desprendiéndose de su antigua voz como creador modernista para dar paso a la gestación de una nueva poética. Incluso, es bastante notable como a medida que se interna en el interior de Colombia, la voz de Arturo Cova tiende a atenuarse para, primero, contaminarse y luego, mimetizarse con el ímpetu y las agendas de los otros narradores ${ }^{7}$ frente a las situaciones de abuso e injusticia que atestigua.

La condición de artiste manqué de Arturo Cova sirve a Rivera para llamar la atención sobre la necesidad de una nueva estética literaria comprometida con la denuncia y solución de los grandes problemas nacionales frente al modernismo decadentista que Cova encarna y que recuerda las ideas de Martí y Rodó que mencionamos al principio del ensayo. En su atropellada trayectoria por la geografía liminar colombiana -llanos y selva-, Cova y su historia son el vehículo para que Rivera exponga, por un lado, la esclavitud que tenía lugar en las caucherías de la selva amazónica y, por el otro, para que subraye la urgencia de reivindicar la soberanía nacional y asegurar el funcionamiento de las leyes en aquella zonas donde cundía, entonces, la fiebre del caucho. Es Balbino Jácome quien denuncia esta situación en la novela por mediación de la voz de Clemente Silva plasmada en los escritos de Cova.

${ }^{6}$ Una künstlerroman o novela del artista es un subgénero de la bildungsroman en la cual se asiste a la maduración de un artista. Así, el lector asiste a los primeros balbuceos del personaje en tanto artista hasta la consolidación de su voz como creador.

7 Eduardo Thomas D. identifica este recurso como la llamada estructura de mise en abyme y señala que ella es "la realización del proyecto estético mundonovista que abre el espacio para que el proceso que conduce a Arturo Cova a la dignidad de héroe-poeta se complete, e influye en la recepción de la novela por parte del lector, que deberá recibirla como palabra nueva que aquél, como don, otorga a su pueblo: una literatura nueva, capaz de revelarle su identidad americana" (1991, p. 103). 
Este complejo mecanismo de polifonía -materialización del mise en abyme- constituye la base estructural de la novela: el lector se enfrenta a una serie de narraciones enmarcadas que, con frecuencia, acogen en su interior otras narraciones, las cuales son siempre relatadas desde la perspectiva de Cova. Es de este recurso que Rivera se vale para dotar a su texto de una apariencia de verosimilitud que refuerza, a su vez, la veracidad de cuanto en él se denunciaba. Grosso modo, el marco narrativo de La vorágine sugiere al lector que todo cuanto tiene ante sus ojos son los escritos que el propio Arturo Cova anotara en el libro de caja del Cayeno y que pusiera en manos del viejo Clemente Silva para relatar lo que ocurría en aquella región de Colombia ante el cónsul colombiano en Manaos. Para fortalecer esta estrategia narrativa encaminada a crear un aura de veracidad alrededor de lo que se denuncia en el texto, el mismo José Eustasio Rivera se ficcionaliza. Se convierte en un fautor ${ }^{8}$ del texto y aparece mencionado en su prólogo confesando haber preparado un glosario -que se encuentra al final del libro-, no haber alterado el cuerpo de los escritos de Cova, al tiempo que hace notar la intención de denuncia que los atraviesa. ${ }^{9}$

Esta estrategia de veracidad la completa la paráfrasis que el Rivera autor de La vorágine hace del comunicado del cónsul colombiano en Manaos sobre la suerte de Cova y sus amigos: "El último cable de nuestro Cónsul, dirigido al señor Ministro y relacionado con la suerte de Arturo Cova y sus compañeros, dice textualmente [...] ‘Los devoró la selva!” (RIVERA, 2006, p. 385). En este breve epílogo, José Eustasio Rivera se consolida como intermediario entre los textos de un personaje de ficción y el mundo no ficcional de los lectores validando, así, la denuncia que se realiza en La vorágine sobre la situación en la Amazonía en el contexto de poderosos intereses trasnacionales involucrados en la región. ${ }^{10}$

${ }^{8}$ Por fautor entiendo lo que José R. Valles Calatrava releyendo a Oscar Tacca define como "un autor-transcriptor [que] corresponde al intento de objetividad y de conseguir verosimilitud de un autor que voluntariamente se oculta y no da muestras de su presencia; adquiriría distintas imágenes: compilador, redactor, depositario, traductor o editor" (2008, p. 236).

9 Lector del Libro rojo (1912) de Norman Thomson que detallaba las operaciones de la Amazon Peruvian Company -presidida por Julio C. Arana- y su papel protagónico en el escándalo del Putumayo, Rivera narra y denuncia, a través de las distintas historias enmarcadas en La vorágine, alrededor de dieciséis años (los años que tenía Clemente Silva de deambular por la selva) de explotación cauchera en la zona.

${ }^{10}$ Ver el excelente estudio que realiza Jennifer L. French (2005) sobre las huellas del neocolonialismo británico en la zona a través de la Peruvian Amazon Company. 
De esta región liminar, el texto de Rivera, además de denunciar los abusos de la explotación cauchera, propone -como von Martius lo hiciera para el Brasil- su plena incorporación a la nación a través de un mapeamiento que va más allá del sentido cartográfico del término." Esa visión totalizadora que busca compensar el desconocimiento de la geografía nacional a través de la escritura marca una coincidencia central de Rivera con Humboldt, Sarmiento y Euclides da Cunha en lo referente al elemento cartográfico sobre el que éstos habían trazado la escritura de sus tratados nacionales. Sin embargo, a diferencia de todos ellos, Rivera utiliza la ficción como punto de partida para la construcción de una visión totalizante de la selva y los llanos colombianos, aunque lo hace a través de una estrategia narrativa que intenta erosionar, precisamente, los límites entre la realidad que intenta denunciar y la ficción literaria que le sirve como vehículo para ello.

Miembro de una comisión limítrofe como, en su tiempo, lo había sido Euclides, Rivera' ${ }^{12}$-designado, en 1922, secretario de la comisión limítrofe colombo-venezolana- permaneció en la selva hasta, por lo menos, julio de $1923,{ }^{13}$ después de adolecer de paludismo, ${ }^{14}$ mientras -

${ }^{11}$ A este respecto, French afirma que "La vorágine picks up the trope of mapping the jungle as a figure for extending national sovereignty into the troubled periphery [...] The novel present the lack of inadequate maps of southern Colombia as a figure for government's general neglect of the borderlands, where there was no reliable system of communication or transportation, little or no government presence, and no legitimate legal authority" (2005, p. 130).

${ }^{12}$ Hay una simetría casi borgesiana entre las biografías y obras de Euclides da Cunha y José Eustasio Rivera que merecería un estudio detallado. Artículos periodísticos de Rivera como "La penetración peruana en el Caquetá" (1924) recuerdan el ciclo anti-peruano de la producción ensayística de Euclides en el que destaca el tratado Peru versus Bolívia de 1907.

${ }^{13}$ Con respecto a la expedición de 1922 al sur de Colombia en la que Rivera fue nombrado secretario en la comisión para estudiar el problema de deslinde territorial con Venezuela, Jennifer L. French detalla que acompañado por Larrazabal, ingeniero y jefe de la expedición, "Rivera descended southeast from the capital to [...] the dense jungles where the territorial limits of Colombia, Venezuela, and Brazil meet" (2005, p. 129). Posteriormente, llegaron a Belém pasando por Manaos, en el Brasil.

${ }_{14}$ "The expedition" -comenta French- "ended in frustration and a disagreement that continued for months afterward: Rivera accused several of the other officials, including his direct superior, Justino Garavito, and the commission's leader, Julio Garzón Nieto, of unpatriotic negligence in failing to perform their duties and the commission separated into two groups before returning to Bogotá. Afterward, Rivera maintained that he had hired two Indian guides to and explored by canoe the little-known waterways surroundings the Inírida River, briefly losing their way in the dense jungle" (2005, p. 128). 
según han demostrado investigadores como Neale-Silva ${ }^{15}-$, recopilaba documentos y testimonios que habrían de dar origen a no pocas de las páginas de La vorágine. ${ }^{16}$ Como en el caso de Euclides, la llegada al espacio natural en Rivera se realiza bajo la forma de una expedición auspiciada por el estado que buscaba afirmar su legitimidad en aquellos territorios distantes y no, como en el caso de Quiroga, para materializar una utopía que contravenía los ideales civilizatorios. Así, pues, además de escribir los márgenes para incorporarlos, Rivera, al igual que Euclides, denuncia y critica el status quo en aquella región como un gesto de nacionalismo ${ }^{17}$ frente a las incursiones venezolanas, peruanas y de los explotadores del caucho. Si la desaplicación de las leyes del estado colombiano en aquellas regiones ponía en entredicho su soberanía era como consecuencia implica Rivera- del desconocimiento que se tenía sobre ellas y sobre su pertenencia a Colombia. ${ }^{18}$

Ante el desconocimiento que, en la práctica, hacía de aquel territorio una terra incognita, en La vorágine, Rivera entrega al lector una representación de la selva como un espacio amenazado por intereses extranjeros que ponían en riesgo la soberanía colombiana buscando, quizá, motivar una actuación del estado en la zona que remediase la situación. En consecuencia, se figura a una selva poblada y transitada mayormente por extranjeros -venezolanos, brasileños, peruanos, judíos, italianos, sirios, libaneses, franceses y turcos- de quienes Cova y sus

${ }_{15}$ Véase su Horizonte humano: vida de José Eustasio Rivera (1960).

${ }^{16}$ La inspiración para la parte que trata de los llanos la habría adquirido durante su trabajo como abogado de José Nieto, un terrateniente de la región de Casanare entre 1918 y 1920. En 1922 vuelve a Sogamoso (Casanare) donde comienza la escritura de La vorágine.

${ }^{17}$ En su obra amazónica, Euclides expresa su nacionalismo a partir de la oposición que realiza en sus textos entre el Brasil y el Perú. A través de sus contrastes y confrontos, Euclides opone la fortaleza de la senda histórica del pueblo brasileño -gracias, entre otras causas, a la vena bandeirante- frente a lo que él califica como avatares caóticos del Perú. Para Euclides, Brasil es la única nación facultada tanto por la historia como por la naturaleza para legitimar su soberanía sobre aquella región de la Amazonía. En textos como "Brasileiros" (1909), por ejemplo, ilustra cómo el origen del interés peruano en la Amazonía y de su presencia en ella provenían de la destreza natural de ciudadanos brasileños al servicio del gobierno peruano en la zona. La superioridad brasileña frente a la peruana se legitima, incluso, desde la naturaleza misma: Euclides subraya la preeminencia de la brasileña Heveas brasiliensis frente a la peruana Castiloa ulei ("Os caucheiros").

${ }^{18}$ Hilda Soledad Pachón Farías sostiene que "parte de su grandeza [de José Eustasio Rivera al escribir La vorágine] está en el haber contribuido a la unidad nacional al integrar a su país vastos territorios que permanecían en el olvido mediante el recurso de dárselos a conocer a sus compatriotas" (1993, p. 58). 
compañeros son víctimas en su paso por aquella zona. Por ende, no es poco simbólico que el acto escritural de Cova -encaminado a denunciar y poner un remedio a aquella situación- se efectúe precisamente en uno de los cuadernos de los que se servía el Cayeno -un francés que es el epítome del colonialismo económico que sufría la región- para documentar la explotación del territorio nacional colombiano por medio de la esclavitud de sus propios ciudadanos.

El periplo de Cova es, al mismo tiempo, un pretexto para que, en la más pura tradición de von Martius, Rivera inscriba en Colombia aquel espacio a través de una recreación literaria que se nutre de la visión etnográfica y antropológica para registrar el habla de la región, sus creencias y supersticiones (como en el caso del hechizo de la negra Bastiana y la leyenda de la indiecita Mapiripana ${ }^{19}$ ) e, incluso, el modus vivendi de unos de sus grupos indígenas -los guahibo- entre quienes el mismo Cova vive por un tiempo. De hecho, al documentar su estancia con los indígenas, Cova perpetúa una perspectiva de incomprensión que lo liga a los primeros europeos que escribieron sobre América en el siglo XVI. ${ }^{20}$

Esta perspectiva de insensibilidad en Cova ante los indígenas experimenta una transformación hacia el final de la novela cuando expresa su conmiseración ante la miseria en que vivían dos niñas indígenas que habían sido obligadas a servir como prostitutas en una cauchería.

Así, pues, retrato y denuncia van de la mano en esta descripción pormenorizada y, a la vez, totalizante de la selva a la que Rivera -mientras subsana la condición de terra incognita de este espacio- enfrenta al lector y de la que Horacio Quiroga en su carta elogiara y definiera como una impresión mayor de ambiente. Para alcanzar esa impresión mayor de ambiente, Rivera continúa la apropiación paradójica que tanto Rangel

${ }^{19}$ Es falsa la supuesta oriundez amazónica de la leyenda de la indiecita Mapiripana. Haciendo un pastiche de la variada mitología de la región, a la que, a su vez, amalgamó la figura de la femme fatale de la estética del fin de siècle, Rivera logró crear un relato que es sumamente significativo en el marco del argumento de La vorágine. La técnica del pastiche que funde mitos y leyendas indígenas habrá de ser retomada en el Brasil por Mário de Andrade en Macunaíma (1928).

${ }^{20}$ La aserción de Cova recuerda las líneas de Gandavo en su Tratado sobre a Terra do Brasil (c. 1573) sobre los indígenas de la costa brasileña: "a língua deste gentio toda pela Costa he, huma: carece de três letras -scilicet, não se acha nella F, nem L, nem R, cousa digna de espanto porque assi não têm Fé, nem Lei, nem Rei; e desta maneira vivem sem justiça e desordenadamente" (1980, p. 52). 
como Quiroga y el mismo Güiraldes hacen de la estética del decadentismo finisecular -centrada mayormente en la descripción de joyas, piezas de museo e, incluso, de las llamadas nature morte- para retratar la naturaleza americana en un espectro que oscila entre el costumbrismo, el ufanismo y el tremendismo naturalista. Rivera acuña una retórica del exceso cuyo barroquismo y repertorio de imágenes recuerdan el estilo con el que Alberto Rangel describiera la Amazonía brasileña en Inferno verde (1907) y que, en cierta manera, son un reflejo de la espesura y el abigarramiento de la vida natural en la selva. De hecho, el título del texto de Rangel expresa la visión con la que se concibe, en parte, el espacio selvático en $L a$ vorágine; es la cárcel verde.

La figuración de la selva a lo largo de la novela no es estable. Antes bien, pasa por una serie de transformaciones que acontece de manera paralela a la gestación de la nueva voz como creador -en el marco de la ya aludida künstlerroman- de Arturo Cova. Al principio de La vorágine y de cara a lo que se narra en De sobremesa y Raucho, la selva sustituye a París en tanto espacio a donde el joven protagonista marcha a curarse del ennui. ${ }^{21}$ De ello son prueba las descripciones donde la jungla es referida como si se tratase de enormes templos o edificios delineados, a su vez, por amplias avenidas acuáticas. Estas naves ilusorias -que se antojan edificaciones góticas- reflejan ese espíritu de morbidez y malditismo tan caro a los modernistas: "aquel ambiente de pesadilla me enflaquecía el corazón, y era preciso volver a las tierras civilizadas, al remanso de la molicie, al ensueño y la quietud" (RIVERA, 2006, p. 180). De hecho es precisamente en su primera pesadilla ${ }^{22}$ que Cova realiza una conexión simbólica que se mantiene constante a lo largo del texto: me refiero a la relación entre la selva y la mujer, que era la misma que se daba entre la mujer y París en Raucho. En su pesadilla, Arturo se sueña persiguiendo

${ }^{21}$ A diferencia de Raucho, que casi es devorado por el espacio vampírico del París retratado en la novela, a Cova y sus compañeros sí los engulle la selva tropical. Sin embargo, propongo que en ambos casos hay una salvación/regeneración que acontece por mediación de la naturaleza. En Raucho tal salvación es más fácil de ser captada: el protagonista se salva al regresar a las pampas argentinas. En Rivera, por otro lado, la cuestión de la salvación ocurre de manera menos obvia. La muerte de Cova en la selva es el acto final de reconciliación con la tierra tras la epifanía que lo había hecho reorientar su voz, su escritura y prestar un servicio a la patria a través de la elaboración de los manuscritos denunciatorios entregados a Silva.

${ }^{22}$ Esta pesadilla y el final del relato que cierra la conexión Inferno verde de Alberto Rangel guardan estrechísimas correspondencias simbólicas y estéticas. 
a una Alicia huidiza que, al final, resulta ser el mismo árbol del que éste, a hachazos, intentaba extraer caucho: “¿Por qué me desangras?, suspiró una voz falleciente. Yo soy tu Alicia y me he convertido en una parásita" (RIVERA, 2006, p. 112). El carácter agreste de la selva se transforma, entonces, en eco de la mujer figurada en términos de la femme fatale del decadentismo. Este perfil lo actualizan la propia Alicia -en momentos-, la niña Griselda, Zorayida Airam e, incluso, la indiecita Mapiripana. Sin embargo, la más trascendental de estas figuras femeninas es la selva misma en que se convierte hacia el final, a despecho del reencuentro con Alicia, la protagonista de la novela al lado de Cova.

A diferencia del perjuicio espiritual que el viaje a París provocaba en sus ejecutantes -según lo detalla el narrador de Raucho- el viaje a la selva representa para Arturo Cova, como veníamos anticipando, una oportunidad para redefinir su identidad como escritor y corregir su estética frente a la naturaleza americana. Así, a pesar de la contradicción que implica su visión en los llanos cuando se sueña patriarca de un hato ${ }^{23}$ -como sí lo será el Santos Luzardo de Doña Bárbara-, Cova experimenta una metamorfosis al entrar a la selva y conocer a Clemente Silva y el universo de los caucheros. Cuando esto ocurre, la figuración de la selva, en consecuencia, se realiza en términos que evocan la esclavitud y el régimen de opresión e injusticias en el que pasaban sus días los hombres con quienes Cova interactúa en su busca de Alicia. Así, la selva se transforma en cárcel verde, en prisión, en infierno, en cementerio, en la materialización de "un abismo antropófago, la selva misma, abierta ante el alma como una boca que se engulle los hombres a quienes el hambre y el desaliento le van colocando entre las mandíbulas" (RIVERA, 2006, p. 307).

Media, pues, una larga trayectoria entre el Arturo Cova megalómano, narcisista y víctima del ennui del principio de la novela y el protagonista que, hacia el final de la misma, oscurece su voz para dar paso al relato y la denuncia de los caucheros y de cuanto él mismo atestiguaba en su camino

${ }^{23}$ Reproduzco aquí un fragmento de ese pasaje de raigambre romántica: “¿Para qué las ciudades? Quizá mi fuente de poesía estaba en el secreto de los bosques intactos, en la caricia de las auras, en el idioma desconocido de las cosas; en cantar lo que dice al peñón la onda que se despide, el arrebol a la ciénaga, la estrella a las inmensidades que guardan el silencio de Dios. Allí en esos campos soñé quedarme con Alicia, a envejecer entre la juventud de nuestros hijos, a declinar entre los soles nacientes, a sentir fatigados nuestro corazones entre la savia vigorosa de los vegetales centenarios, hasta que un día llorara yo sobre su cadáver o ella sobre el mío" (RIVERA, 2006, p. 161). 
por la selva. La aserción pesimista -fragmento de su carta- que abre $L a$ vorágine, muestra a un Cova que confiesa el fracaso de su vida dada la improductividad con que la caracteriza. Utiliza, significativamente, una metáfora de índole vegetal para expresar su desaparición trágica en el agreste: "el destino implacable me desarraigó de la prosperidad incipiente y me lanzó a las pampas, para que ambulara vagabundo, como los vientos, y me extinguiera como ellos sin dejar más que ruido y desolación” (RIVERA, 2006, p. 77). Esta imagen de esterilidad se reafirma páginas más adelante cuando al hablar de la marcha de Alicia a su lado, se describe a sí mismo oblicuamente diciendo que "ella iba también, como la semilla en el viento, sin saber a dónde y miedosa de la tierra que la esperaba" (RIVERA, 2006, p. 87). La imagen de la semilla al viento para resumir la vida de Cova es, a todas luces inexacta, si consideramos que es gracias a su trayecto en la selva que se cierra el ciclo de esta künstleroman à rebours o, en otras palabras, que Cova logra recrearse y, a su vez, regenerar su voz como escritor. Del poeta del principio poco queda cuando páginas antes del final éste experimenta una epifanía y se pregunta sobre la trascendencia de la estética romántica en situaciones como la que atravesaba: “¿Cuál es aquí la poesía de los retiros, dónde están las mariposas que parecen flores translúcidas, los pájaros mágicos, el arroyo cantor? ¡Pobre fantasía de los poetas que sólo conocen las soledades domesticadas! (RIVERA, 2006, p. 296). Distanciándose, pues, de las fantasías de esos poetas de quienes había formado parte, Cova concibe para su escritura una finalidad: la de ayudar a resarcir los abusos que veía y contribuir, así, al mejoramiento de la nación.

Trazados con ánimo febril, los escritos que produce Cova sobre uno de los cuadernos de contabilidad del Cayeno, símbolo de aquel sistema de explotación esclavista, ${ }^{24}$ constituyen, a mi parecer, la fertilidad que el

${ }^{24}$ Tulio Halperin Donghi afirma que hay una diferencia capital entre la dialéctica de la explotación cauchera y sus efectos en el Brasil y la que tuvo lugar en Colombia, Ecuador, Perú y Venezuela: "En la Amazonia colombiana, ecuatoriana, peruana y venezolana, la explotación [cauchera] es aún más primitiva y destructiva; a falta de las reservas de mano de obra que el Nordeste ofrecía en Brasil, debe disciplinar mediante violencia y crueldad aún mayores la más escasa [mano de obra] efectivamente disponible; en la búsqueda de rápidos provechos se destruyen los árboles mismos, que en Brasil son sólo sangrados periódicamente, pues el mantenimiento del stock está en el interés del seringueiro, que no puede cosechar sino la zona que le ha sido asignada y sería la primera víctima de la desaparición de los árboles. La ola de explotación destructiva avanza así sobre la Amazonia peruana, destruyendo las plantaciones naturales y también el modo de vida de poblaciones neolíticas, arrojadas a participar en la economía del siglo XX mediante el doble estímulo del alcohol y el terror" (1990, p. 319). 
protagonista de La vorágine alcanza y por la que se redime a través de la escritura. Concebidos con la selva -cuyo protagonismo ya señalamosestos escritos nacen al amparo de dicho espacio y, al igual que el ritual de paternidad que Cova describía entre los indios guahibo, es él quien, simbólicamente, da a luz a la criatura y deja de ser aquella semilla al viento a la que hacía referencia al inicio de La vorágine. La descendencia de Cova no la constituye, sin embargo, el hijo que pare Alicia en medio de la selva, sino el libro donde además de perpetuarse él mismo -a través de sus memorias-, presta un servicio ejemplar a su nación: "[Don Clemente] Cuide mucho esos manuscritos y póngalos en manos del Cónsul. Son la historia nuestra, la desolada historia de los caucheros. ¡Cuánta página en blanco, cuánta cosa que no se dijo25!" (RIVERA, 2006, p. 383-384).

$\mathrm{Al}$ igual que en Raucho, el protagonista de La vorágine, comprueba su transformación y reconciliación con la tierra no sólo deshaciéndose de su ropaje previo, sino, sobre todo, identificándose y convirtiéndose en uno de aquéllos cuya situación relata en sus manuscritos. Cova muere tragado por la tierra, pero ese acontecimiento más que ser leído sólo como un hecho trágico debe ser entendido como una reconciliación, una reincorporación orgánica al suelo americano.

Es, también, la reconciliación con el suelo americano-comoveíamos en Raucho y, posteriormente, en La vorágine- la senda que el protagonista de Doña Bárbara (1929) recorre a lo largo de esta novela que Rómulo Gallegos ambienta en otro espacio periférico: la región de los llanos en Venezuela. Aunque heredera del espíritu de Sarmiento -en lo referente al préstamo explícito que hace de los términos civilización y barbarie-, Doña Bárbara es, como veremos, una obra que se apega más a las posiciones de Martí en Nuestra América y de Rodó en Ariel en lo que respecta a la resolución de la problemática de América Latina o, para decirlo en la especificidad de la misma obra: de la "tragedia venezolana"26 (GALLEGOS, 2004, p. 113).

${ }_{25}$ Asimismo, al poner este libro en manos de Clemente Silva, Cova le restituye simbólicamente al viejo los huesos de su hijo Luciano en cuya memoria había decidido arriesgarse a viajar a Manaos y denunciar los atropellos contra los caucheros en la selva. Las siguientes líneas pronunciadas por Silva ante Zoraida Airam apoyan lo anterior; la estrecha relación entre el libro y el hijo: “¡Colombia necesita de mis secretos! ¡Aunque muriera inmediatamente! ¡Ahí le queda mi hijo para luchar!” (RIVERA, 2006, p. 281).

${ }^{26}$ Gallegos, según Jerry Hoeg, trata de "orchestrate a new solution to the problems engendered by the barbarous behavior he sees as ubiquitous in Latin America, namely the anarchy, civil war, and despotism that had followed closed on the heels of political independence" (RIVERA-BARNES; HOEGH, 2009, p. 118). 
Consumación del género de las llamadas novelas de la tierra, Doña Bárbara conjuga la figuración amenazante de la naturaleza que tenía lugar en La vorágine al tiempo que inscribe los hechos relatados en clave alegórica dentro de la narrativa de tesis al modo de Raucho. La alegoría no sólo explica la génesis de esta novela, sino que es también un elemento esencial para el entendimiento del plan que, a través de ella, Gallegos -en el más puro espíritu Sarmientino ${ }^{27}$ - expone para consolidar el desarrollo de Venezuela y conjurar las fuerzas retrógradas que dificultaban su avance concentradas en la figura de doña Bárbara. Es, de hecho, en el prólogo que antecede a la última versión preparada y revisada por el propio Gallegos donde éste desvela la clave alegórica de la obra y establece dicha interpretación sobre cualquier otra que pudiere dársele. Es, asimismo, en el prólogo que Gallegos elabora un manifiesto donde cifra la postura ideológica que debían adoptar un escritor y su obra frente a los desafíos que enfrentara su nación en el espíritu de los ensayos de Martí y Rodó que aludimos arriba.

En el prólogo, Gallegos condena oblicuamente la literatura escapista y se decanta, en cambio, por una escritura que se interese y esté involucrada en los acontecimientos reales que rodeasen al escritor. Al reafirmar la dimensión lúdica que subyace la lectura de toda novela, sugiere que el escapismo de la ficción es legítimo sólo cuando las circunstancias externas lo posibiliten: es decir, cuando estén paradas las máquinas de los disparates y monstruosidades. Por eso, al tener en cuenta el momento histórico en que esta obra se escribió -la larga dictadura de Juan Vicente Gómez $^{28}$-, es entendible que Gallegos subraye -como Rivera hiciera en La vorágine- el hecho de que los personajes que aparecen en su texto son reales implicando, así, que su novela es mucho más que un objeto lúdico y él, más que un escritor de ficciones.

La escritura es resignificada como un servicio a la nación que trasciende cualquier afán literario. Gallegos confiesa haber abandonado

${ }_{27}$ Al igual que Sarmiento en la Argentina, Gallegos llegaría a ser presidente de Venezuela entre febrero y noviembre de 1948 antes de ser depuesto por un golpe de estado. Gallegos fue el primer presidente elegido democráticamente en Venezuela a su regreso de un exilio causado por sus críticas al entonces dictador Juan Vicente Gómez en la novela que analizamos.

${ }^{28}$ Según Patricia Lapolla Swier (2009), Gallegos evoca en el proceder de doña Bárbara las tácticas de las que se hizo Juan Vicente Gómez para llegar al poder y para mantenerse en él. 
la intención de escribir una novela de impresiones y paisajes de los llanos al experimentar de cerca los conflictos de Venezuela en quienes conociera en su viaje por las latitudes aludidas en Doña Bárbara.

Escribir es, pues, en Gallegos -como Martí lo ambicionara con su "pensar es servir" en Nuestra América- servir y, además hacer la patria. Con Doña Bárbara, Gallegos, en el marco de un optimismo nacionalista, ofrece un servicio a Venezuela al utilizar la escritura como vehículo para proponer soluciones al atraso nacional desde una ficción con pretensiones de ensayo político: "el espectáculo no era para reflexiones pesimistas, y mi venezolano deseo de que todo lo que sea tierra de mi patria alguna vez ostente prosperidad y garantice felicidad, tomó forma literaria" (RIVERA, 2006, p. 110-111).

Así, al utilizar el espacio de la ficción como un campo de cultivo propicio para la generación de soluciones a las grandes cuestiones nacionales, Gallegos se distancia en Doña Bárbara de la tópica modernista de novelas como Ídolos rotos (1901) y Sangre patricia (1902) del también venezolano Manuel Díaz Rodríguez. ${ }^{29}$ En dichos textos de Díaz Rodríguez los protagonistas son venezolanos desarraigados que acaban por huir a Europa dejando atrás la "tierruca" (Ídolos rotos, p. 41) -como es aludida Venezuela- pues, como afirma Alberto Soria, protagonista de Ídolos rotos, "el supremo deber de un artista es poner a salvo su ideal de belleza. Y yo nunca, nunca, realizaré mi ideal en mi país” (p. 162). Contraponiéndose a lo anterior, la postura de Gallegos establece un vínculo estrechísimo entre el artista, su estética y el arte que éste habría de producir de cara a lo que el autor denomina "ese desgraciado tiempo de mi país" (GALLEGOS, 2004, p. 112).

Al principio de la novela, su protagonista -Santos Luzardo-, al igual que Alberto Soria y Tulio Arcos de Ídolos rotos y Sangre patricia, respectivamente, ambiciona finiquitar toda relación con Venezuela y mudarse a Europa a consecuencia de la intermediación libresca y la morigeración de su virilidad por influjo de la atmósfera feminizante con

29 Díaz Rodríguez y Gallegos se posicionaron en extremos opuestos frente a la dictadura de Juan Vicente Gómez. Según Morena Carla Lanieri, “entre 1908 y 1920 Díaz Rodríguez será ministro del dictador Juan Vicente Gómez y hasta su muerte (1927) guardará silencio ante los crímenes de la tiranía, sin que su responsabilidad como escritor frente a la realidad de su país lo inste a denunciarlos" (2004, p. 277). 
la que se asocia a la ciudad..$^{\circ}$ Tal y como se ve también en el Raucho de Güiraldes, a su llegada a la ciudad, Luzardo es seducido por la vida urbana que descoyunta sus lazos de pertenencia a la nación y, en consecuencia, elimina toda posibilidad de fertilidad en el ejercicio de su ciudadanía a la que parece querer renunciar. Santos adopta esa actitud que Martí condenaba en Nuestra América al calificar a hombres que encarnaban tal espíritu como sietemesinos "que no tienen fe en su tierra [...], delicados que son hombres pero que no quieren hacer la labor de hombres" (GALLEGOS, 2004, p. 54). Santos Luzardo, más que interesarse en la vida de Venezuela proyectando su regreso al solar de su familia en los llanos -microcosmos mismo de la patria-, vive anhelando el exilio en Europa.

En oposición a la trayectoria del protagonista en Raucho, Santos Luzardo llega a la ciudad procedente de un espacio rural cifrado como locus del caos, la violencia e, incluso, del fratricidio. Esta interrupción de la armonía en el campo, provocada por la desintegración del linaje de los Luzardo, expresa el fin de una aurea aetas que Gallegos convierteen alegoría dela descomposición y las luchas intestinas que sufría la Venezuela de aquel tiempo. Buscando "salvarlo, educándolo en otro medio, centenares de leguas de aquellos trágicos sitios" (GALLEGOS, 2004, p. 135) la madre lo lleva a Caracas donde, paradójicamente, Santos ante el efecto nocivo de la vida citadina, manifiesta síntomas del ennui libresco: adolece de un "adormecimiento", "atrofia” y "abulia” espirituales. Así, pues, mientras que Raucho es trasladado al campo para que la naturaleza ocupase la figura maternal con la que su orfandad le impedía contar, Santos es alejado de ella porque se la concibe como un espacio amenazante que bestializa o, como la describe Lorenzo Barquero, una "tierra [que] no perdona [...] la devoradora de hombres" (GALLEGOS, 2004, p. 217). No obstante, la ciudad prueba representar una opción errónea para la salvación de Santos puesto que su ambiente y el espejismo libresco que lo envuelve invitan a la extinción de los vínculos con el hato y, por ende, con la patria misma. A la enfermedad simbólica de la patria, Gallegos añade

$3^{30}$ De esta feminización es prueba la mirada inquisitiva y reprobatoria que uno de los trabajadores del hato despliega sobre Santos a su regreso de Caracas: "del concepto que tenía Carmelito de la hombría estaba excluido todo lo que descubrió en Santos Luzardo [...] la gallardía, que le pareció petulancia; la tesura del rostro, la delicadeza del cutis ya sollamado por el resol de unos días de viaje, rasurado el bigote, que es atributo de machos; los modales afables, que le parecieron amanerados; el desusado traje de montar, aquel saco tan entallado, aquellos calzones tan holgados arriba y en las rodillas tan ceñidos, puños estrechos en vez de polainas, y corbata, que era demasiado trapo para llevar encima por aquellas soledades" (GALLEGOS, 2004, p. 157). 
el panorama poco halagüeño del contagio escapista de su protagonista evocando, quizá, las siguientes líneas de Martí.

A la pregunta retórica de Martí, Gallegos opone la trayectoria de regeneración de Santos a lo largo de Doña Bárbara. Su contacto con la tierra de sus antepasados lo cura del ennui y restituye en él su compromiso con la restauración de Altamira que es, a la vez, la de Venezuela misma.

Artífice de la separación de su hijo de la tierra, será la misma doña Asunción quien recuerde a Santos la importancia que detenta Altamira en tanto constituía el origo familiae de los Luzardo. Es, pues, su muerte el acontecimiento que posibilita la reconexión de Santos con la tierra. Su vuelta al hato es bastante simbólica puestoque representa un regresoal origen donde no sólo se reivindica su ligazón con la tierra en el sentido de conservación del solar familiar, sino también y, sobre todo, se reafirma compromiso con la patria que Santos elabora bajo la forma de su plan civilizador de la llanura durante su viaje fluvial rumbo a Altamira. A través de dicho plan y la derrota de doña Bárbara, el protagonista recupera ese territorio para la patria al reinstaurarlo al marco de la legalidad del estado, tal y como pretenden hacer las denuncias de Cova con la Amazonía colombiana en La vorágine.

Esta trayectoria a la tierra que lo hace retomar el mando de Altamira implica para Santos, además de una reconciliación con sus antepasados y un acto de fe hacia la nación, la resolución del enfrentamiento entre la civilización y la barbarie. Sin renunciar a su esencia llanera -"llanero es llanero hasta la quinta generación” (GALLEGOS, 2004, p. 358)-, Santos decide acoplarla a los ideales que la educación en Caracas le había inculcado: “decidió lanzarse a la empresa con el ímpetu de [...] los hombres de una raza enérgica; pero también con los ideales del civilizado, que fue lo que aquéllos les falto" (GALLEGOS, 2004, p. 140). En ello radica la contribución de la obra de Gallegos; en reconciliar los términos de la dicotomía sarmientina sin desechar ninguno de ellos. Gallegos lo hace a través de la transformación de la figura de Santos Luzardo por el contacto telúrico ${ }^{31}$ y de su unión con

${ }^{31}$ Luzardo abraza para sí la metáfora del centauro aludida a lo largo de la novela como una materialización oprobiosa del espíritu de desenfreno y violencia que se apoderaba de los hombres que habitaban los llanos: "Es necesario matar al centauro que todos los llaneros llevamos por dentro [...] El centauro es la barbarie y, por consiguiente, hay que acabar con él" (GALLEGOS, 2004, p. 215). Sin embargo, esta metáfora es resignificada por Gallegos a través de la conciencia de propagador de la civilización que hay en Santos. El protagonista recupera su hombría a través del contacto con la barbarie mientras persevera desde su conciencia civilizatoria para instaurar el orden y allanar el camino hacia el progreso en los llanos. 
Marisela mientras desarticula, a la vez, la dictadura de la ignorancia y la superstición que doña Bárbara instaurara en los llanos.

Como veíamos, el deslinde que, en el prólogo, hace el autor de la estructura alegórica de la novela sitúa la problemática de lo que en ella se narra en el plano de la matriz antinómica sarmientina de civilización contra barbarie. Sin embargo, a diferencia del pesimismo y el racismo frente a lo americano que entrañan y en los que se fundan las aseveraciones del pensador y presidente argentino, la postura de Gallegos en Doña Bárbara supone una evolución con respecto al discurso determinista que venía arrastrándose desde el siglo XIX. Si bien explica que doña Bárbara es la representación de la barbarieamericanay de las fuerzas de dicha naturaleza mientras que Santos Luzardo es la materialización de la civilización, Gallegos -más que pensar en una eliminación o sometimiento de la barbarie por parte de la civilización propugna por una unión productiva entre ambos. La manera en que se realiza esa unión es a través de la síntesis erótica ${ }^{32}$ de Marisela -hija de doña Bárbara-y de Santos Luzardo que, hacia el final de la novela, refundan, de manera simbólica la nación venezolana: "Santos Luzardo y Marisela [...] son, respectiva y complementariamente, la empresa que hay que acometer, una y otra vez, y la esperanza que estamos obligados a acariciar con incansable terquedad; la obligación de hoy para la sosegada contemplación de mañana" (GALLEGOS, 2004, p. 112).

La unión entre Santos y Marisela es consecuencia de un proceso mucho más crucial en el argumento del texto. De hecho, se trata de la línea principal de la novela. En ella se detalla el proceso a través del cual el obstáculo para el progreso de la región -doña Bárbara; es decir, la naturaleza- es superado. La personificación de la naturaleza, su caracterización como doña Bárbara, revelan que, al igual que sucede en Raucho y La vorágine, la figura femenina detenta también en esta novela un rol central. Descrita como "marimacho" (GALLEGOS, 2004, p. 154) o "mujer de pelo en pecho" (GALLEGOS, 2004, p. 188), doña Bárbara encubre bajo la intensidad de su fuerza, de su condición hombruna el trauma de una mujer -evocación de la indiecita Mapiripana de La vorágine- que tras ser estuprada se ve impedida de la maternidad: "la trágica guaricha.

${ }^{2}$ Una unión erótica que pasa por el proceso del tipo que detalla Doris Sommer: "Once the couple confronts the obstacle, desire is reinforced along with the need to overcome the obstacle and to consolidate the nation. That promise of consolidation constitutes another level of desire and underscores the erotic goal, which is also a microcosmic expression of nationhood" (1991, p. 49). 
Fruto engendrado por la violencia del blanco aventurero en la sombría sensualidad de la india, su origen se perdía en el dramático misterio de las tierras vírgenes" (GALLEGOS, 2004, p. 141). El conflicto central en el texto de Gallegos es, pues, cómo doña Bárbara no sólo es derrotada por la prevalencia de la "obra patriótica" (GALLEGOS, 2004, p. 171) que conlleva el plan modernizador de la llanura emprendido por Santos Luzardo desde Altamira, sino, sobre todo, cómo la naturaleza agreste -a quien doña Bárbara representa- es impulsada a generar, a producir, a ser maternal. Es ése, precisamente, el sentimiento que la unión entre Santos Luzardo y Marisela despiertan por primera vez en aquella mujer antes de su desaparición definitiva de los llanos: "Se quedó contemplando, largo rato, a la hija feliz, y aquella ansia de formas nuevas que tanto la habían atormentado tomó cuerpo en una emoción maternal, desconocida para su corazón" (GALLEGOS, 2004, p. 464).

Así, pues, el estado indómito y salvaje que Santos Luzardo atestigua en la naturaleza, al principio de la novela, es sucedido por la inminencia de una visión donde se enfatiza la productividad del medio gracias a la victoria de su plan civilizatorio. Santos anuncia el advenimiento de los ferrocarriles al hasta entonces reducto geográfico de la barbarie y confirma, así, su propia fertilidad -en tanto ciudadano- hacia el proyecto de nación que Gallegos propone en la novela:33 "la línea recta del hombre dentro de la línea curva de la Naturaleza, demarcaría en la tierra de los innumerables caminos, por donde hace tiempo se pierden, rumbeando, las esperanzas errantes, uno solo y derecho hacia el porvenir" (GALLEGOS, 2004, p. 234). Lo anterior marca un decisivo contraste con el pesimismo que caracterizaba la concepción de Venezuela en las novelas de Díaz Rodríguez y, en general, de la estética anterior a Gallegos. Habiendo asimilado el desahucio determinista presente en Sarmiento, en una de sus obras, Díaz Rodríguez llegó a comparar a la nación con un organismo vegetal contrahecho y malsano.

A ello, Gallegos opone una lectura que, si bien se sirve de la terminología sarmientina, se distancia de su desconfianza y profundo escepticismo en el componente racial americano. El autor sugiere que la población es capaz de efectuar el desarrollo de la región guiada por un

${ }^{33} \mathrm{Al}$ respecto, Hoeg comenta que la "civilization triumphs by 'modifying nature', that is, by converting the natural environment into a civilized, cultured, and legally demarcated contryside" (RIVERA-BARNES; HOEG, 2009, p. 120). 
plan que recuerda las propuestas martinianas: una serie de medidas elaboradas sobre la realidad de la naturaleza americana misma y que involucrasen al hombre natural en el proceso de su propio progreso:34 “¿Llanura venezolana! ¡Propicia para el esfuerzo, como lo fue para la hazaña! Tierra de horizontes abiertos, donde una raza buena, ama, sufre y espera!" (GALLEGOS, 2004, p. 468). Doña Bárbara es una propuesta para remediar esa condición de espera del interior americano que Gallegos enfatiza como un desafío a la juventud americana a la que Rodó se dirigiera en Ariel.

La reivindicación literaria de la naturaleza y de lo telúrico frente a la estética precedente -el modernismo- que tiene lugar en Raucho, La vorágine y Doña Bárbara, está cimentada sobre una paradoja. A pesar de que estos textos daban la espalda al espacio urbano y sospechaban de todo esteticismo que se apartase del carácter nacional -explicado siempre como una esencia ligada a la tierra y lo vernáculo-, el lenguaje y los tropos a través de los cuales cifran su nacionalismo provienen de las matrices estéticas que los modernistas utilizaran para describir las ciudades y atmósferas burguesas de sus flâneurs. Los recursos estéticos modernistas fueron incorporados por los autores de las novelas de la tierra que los resignificaron al recontextualizarlos y adaptar su utilización en narrativas de tintes didácticos (Raucho) o ejemplarizantes (La vorágine y Doña Bárbara) que se servían de los tonos del costumbrismo, del ensayo político, de la denuncia periodística, del diario para reposicionar a la naturaleza en el centro del debate sobre la nacionalidad. La publicación en 1928 de Macunaíma o herói sem nenhum caráter, escrita por el brasileño Mário de Andrade, representa un giro de tuerca capital frente a la tendencia estética que manifestaban las novelas hispanoamericanas estudiadas anteriormente, las cuales -hay que decirlo- le eran contemporáneas.

Lejos ya del influjo esteticista del parnasianismo -modernismo en Hispanoamérica- a través del cual pampa y selva habían sido descritas en Raucho, La vorágine y Doña Bárbara, Macunaíma manifiesta una filiación estética ligada al vanguardismo europeo que determina su

${ }^{34}$ A este respecto, Lapolla Swier afirma que "Gallegos, therefore, utilized his novel as a means of exposing and subverting the current status of a machista hegemony representative of the dictatorship of Gómez [Juan Vicente Gómez] and sought to replace this oppressive leader with [...] a "buen cacicazgo"' (2009, p. 139). 
deslinde de los últimos trazos de la retórica decimonónica ${ }^{35}$ que aún se evidencia en los textos de Güiraldes, Rivera y Gallegos. En el libro de Andrade, a diferencia de los anteriores, el lenguaje no es sólo instrumento para construir una propuesta de identidad literaria y nacional a través de la descripción de la naturaleza, sino que se convierte él mismo en el protagonista y fuente de la identidad en tanto se lo concibe como la naturaleza del pueblo brasileño. Así, en tanto locus de la identidad, el lenguaje materializa una idea totalizante de lo nacional a través de la superposición del habla y particularidades lingüísticas de todas las regiones del Brasil. ${ }^{36}$ Esto es posible gracias a la narración de una historia proveniente de un ciclo mitológico amazónico ${ }^{37}$ cuyos escenarios son, sin embargo, en el texto de Andrade, la geografía y la historia entera del Brasil. ${ }^{8}$

El viaje al interior y, por ende, el contacto decisivo con la naturaleza que acontecía en Raucho, La vorágine y Doña Bárbara tienen su equivalente en Macunaíma con una vuelta radical al mundo natural. El argumento de la obra no da cuenta de un periplo hacia el dominio de

35 En lo que respecta a la naturaleza vanguardista de Macunaíma, Alfredo Bosi señala que: "todas as grandes aventuras literárias empreendidas na Europa desde o início do século iam nessa direção: transcender o código dito 'realista', ou melhor, positivista, já decaído a clichê de estilo e a estereótipo de personagem. Futurismo, Dadaísmo, Surrealismo, Expressionismo propunham-se captar as imagens de uma nova era da técnica e da velocidade, ou então de um eterno inconsciente, sem prendê-las nas categorias de tempo e espaço tal como as convencionalizara a prática literária do Oitocentos 'burguês'. O denominador comum das novas poéticas era o princípio da libertação: dos gêneros fixos, da psicologia centrada em tipos, da metrificação parnasiana, da prosa rente ao cotidiano domesticado, prosa em que o 'mot juste' era sempre o que se localizava no 'juste milieu"' (1988, p. 173).

${ }^{36} \mathrm{Al}$ respecto, Sérgio Milliet citado por Cavalcanti Proença (1969), afirma que es "a consciência brasileira que leva Mário a encaixar num conto que se passa em São Paulo a sintaxe do Nordeste de permeio com a do Brás, e servir-se em suas imagens do vocabulário amazônico lado a lado com o vocabulário gaúcho [...] tentou descobrir e cultivar o denominador comum do português falado no Brasil” (p. 85).

37 Este ciclo forma parte de las historias de la tradición oral de los yanomamos recogidas por el etnógrafo alemán Theodor Koch Grünberg en Vom Roraima zum Orinoco. II. Mythen und Legenden der Taulipang und Arekuná Indianer (1923) durante su expedición a la zona limítrofe entre la Amazonía venezolana y brasileña entre 1910 y 1913.

${ }^{8}$ Cavalcanti Proença comenta al respecto de este efecto totalizante en el texto. Macunaíma es el héroe "da nossa gente de todos os quadrantes, tem hábitos, crendices, alimentação, linguagem, isentos de qualquer traço regional predominante. Incorpora sem ordem nem hierarquia as características de cultura, diferenciadas nas várias regiões brasileiras. É um herói “desgeograficado’” (1969, p. 82). 
lo natural a través de los ojos de hombres educados en los ideales de la civilización. Andrade articula en Macunaíma una mirada que se proyecta en sentido contrario a las de Raucho, Arturo Cova y Santos Luzardo. Su protagonista -Macunaíma- es un aborigen amazónico, cuya historia constituye el argumento del texto. Es a través de una narrativa lineal y desde la perspectiva del mismo Macunaíma que el lector experimenta el desconcierto que supone su inserción en un universo ajeno que no le es descrito ya desde afuera, sino que se ve y se relata a sí mismo desde adentro. Es, pues, por mediación del discurso etnográfico -en el que se funda Macunaíma-y, en menor medida, del folclórico que desaparece la condición amenazante, misteriosa o idealizada de la naturaleza para dar paso a una visión de índole mitológica indígena que se combina, a su vez, con elementos de la vanguardia europea.

La estrategia de Andrade al convertir el discurso etnográfico en punto de partida de su ficción literaria lo lleva a reconfigurar la figura del indígena y de la naturaleza dentro de la tradición literaria brasileña. Lejos de conformar su figuración del indígena al radio que le permitía el repertorio folclórico o de incurrir en el indianismo esteticista de José de Alencar, en Macunaíma, Andrade concibe el cuerpo del indígena como un espacio donde situar una reflexión crítica sobre la identidad brasileña. Al contrario de la ejemplaridad moral y sentimentalismo que caracterizaban a los personajes indígenas de Alencar como Iracema o Peri, el Macunaíma de Andrade es el epítome de lo que Antonio Candido denominara el malandro39 -“como o pícaro, é espécie de um gênero mais amplo de aventureiro astucioso, comum a todos os folclores" (CANDIDO, 1993, p. 71) cuya "malandragem visa quase sempre ao proveito ou a um problema concreto, lesando frequentemente terceiros na sua solução” (idem) - que deambula en la esfera pública y la privada trascendiendo a través de su comportamiento conceptos como bonhomía y cinismo:40 "que mostra ao leitor uma relativa equivalência entre o universo da ordem e da

${ }_{39}$ Candido estudia la novela Memórias de um sargento de milícias (1852) de Manuel Antonio Almeida en cuyo protagonista -Leonardo-identifica, coincidiendo con Walnice Nogueira Galvão, al predecesor del Macunaíma de Andrade.

${ }^{40}$ Según constata Bosi, el "Makunaíma das tribos da Guiana e da Venezuela amazônica é um ser perigoso, cheio de malícia e perversidade [...] Esse Grande Mau vive no regime do instinto, às soltas, usando da esperteza para escapar aos deveres da sociabilidade adulta" (1988, p. 178-179). 
desordem; entre o que se poderia chamar convencionalmente o bem e o mal" (CANDIDO, 1993, p. 78-79).

Oponiendo el relato de la vida de su malandro a personajes determinados por una trayectoria hacia la conquista de la altura moral en narrativas de maduración a lo bildungsroman o künstlerroman-como era el caso de los protagonistas de las novelas hispanoamericanas analizadas anteriormente-, Andrade critica en Macunaíma la idealización de la construcción identitaria brasileña precedente a través de la historia inconsecuente de un héroe paradójico: de su vida no es viable derivar ni ejemplaridad moral ni línea didáctica alguna. En su lugar, Andrade enfrenta al lector con una sátira corrosiva y escéptica que parodia e ironiza el repertorio cultural brasileño -convertido en pastiche- en el marco de una carnavalización donde conviven tanto el optimismo como el pesimismo de cara a la cuestión de la identidad nacional. ${ }^{41}$

Macunaíma no constituye un ideal, sino un estar em ser-utilizando la frase euclidiana para definir la selva- cuyas acciones se inscriben en una espiral descendente a la que determinan los estímulos freudianos del placer y los del miedo y que Paulo Prado denominara vícios en su Retrato do Brasil42 (1928). En su descripción de las supuestas taras psíquicas del pueblo brasileño, Prado elabora un diagrama psicológico que explicaría la dinámica de acción del protagonista de Macunaíma.43

Esta lógica circular se observa en Macunaíma a pesar de la existencia de un móvil que actualiza la estructura mitológica de la búsqueda: la recuperación del muiraquitã de manos del gigante Piaimã o Venceslau Pietro Pietra "comedor de gente" (ANDRADE, 1988, p. 49). Es, pues, a lo

${ }^{41}$ En este sentido, Macunaíma, al igual que las obras de Paulo Prado, Gilberto Freyre y Sérgio Buarque de Holanda, comparten un espíritu instrospectivo y reflexivo con respecto a la cuestión de la identidad brasileña: "[Macunaíma] se inscreve no quadro de perplexidades que tem por nomes Retrato do Brasil, Casa-grande E senzala, Raízes do Brasil, todas obras pensadas em um tempo dilacerado pelo desejo de compreender o país, acusar as suas malezas, mas remir a hipoteca das teorias colonizadoras e racistas que havia tantos anos pesava sobre a nossa vida intelectual" (BOSI, 1988, p. 179).

${ }^{42}$ De acuerdo con Bosi, el ensayo de Prado era bastante conocido y leído en el Brasil de la época, cuyos intelectuales buscaban explicarlo: "Retrato do Brasil: ensaio sobre a tristeza brasileira é hoje um livro quase esquecido. Quando saiu porém, alcançou êxito excepcional: quatro edições entre 1928 e 1931" (1988, p. 178).

43 Entre Paulo Prado y Mário de Andrade existía una relación de amistad que se fundaba en las mutuas lecturas. De hecho, es a Prado a quien Andrade, significativamente, dedica Macunaíma. 
largo de la narración de esta hazaña que el lector se enfrenta a la paradoja de la aparente ausencia de carácter heroico del protagonista. Sus iniciativas para recobrar el amuleto de $\mathrm{Ci}$-diseñadas desde su condición de malandro y, por ende, de cuestionable altura moral- conviven con una serie de acciones que se revelan contrarias para la consecución de su objetivo. Durante su marcha a São Paulo y su estancia en la ciudad, Macunaíma se involucra en episodios que lejos de llevarlo a la recuperación del muiraquitã crean conflictos que le dificultan la recuperación del talismán. Casi todos ellos están determinados por la continua proclividad del héroe a involucrarse en aventuras sexuales con un amplio catálogo de mujeres, cuyo común denominador-como señala Luís Madureira (2005)- es el juego por el juego mismo y no -como se advertiría en un héroe o modelo para la patria- la procreación: “What is striking about Macunaíma’s frenzied sexual activity is precisely that -in contrast to the foundational romance between Amerindian mother figures and Lusitanian patriarchs- it is not 're-productive"' (p. 103). Blandiendo un lema como "ai! que preguiça!" (ANDRADE, 1988, p. 5) y una lectura de la problemática nacional entre cómica y pesimista resumida en el "pouca saúde e muita saúva, os males do Brasil são!” (ANDRADE, 1988, p. 92), Macunaíma no es un héroe en términos de altura moral o ejemplaridad, sino en su acepción más narratológica: es el protagonista de una rapsodia;44 la rapsodia tropical del Brasil. ${ }^{45}$ Andrade explicaría esta heroicidad al detallar la condición rapsódica de Macunaíma en una carta a Sousa da Silveira en 1935.

Sin embargo, no todo es oposición entre el protagonista de Macunaíma y los de Raucho, La vorágine y Doña Bárbara. En el texto de Andrade hay, también, una profunda convicción con respecto a la condena de la dependencia al capital cultural europeo y la desvalorización del americano. Esto no sólo se manifiesta en el plano del argumento cuando Macunaíma decide no viajar a Europa -"não vou na Europa não. Sou americano e meu lugar é na América. A civilização europeia decerto esculhamba a inteireza do nosso caráter" (ANDRADE, 1988, p. 114-115)-, sino, sobre todo, en el plano lingüístico. En Macunaíma la consolidación

${ }^{44}$ La palabra rapsódia aparecía en la primera edición impresa de Macunaíma como parte del título del libro.

${ }^{45}$ La peculiaridad de la civilización brasileña habrá de ser estudiada por Gilberto Freyre en Casa-grande E senzala (1933) y Sérgio Buarque de Holanda en Raízes do Brasil (1936). 
identitaria brasileña comienza y se consolida en la lengua. Siguiendo los pasos de José de Alencar y trascendiendo su busca de una lengua nacional, Andrade reivindica la independencia lingüística de Brasil con respecto al portugués europeo. En capítulos como el de "Carta pras icamiabas", Andrade condena el hecho de que los escritores brasileños prefiriesen el portugués anquilosado de raigambre europea a la lengua hablada en el país al que él denomina brasileiro. En consecuencia, el libro se convierte en un espejo de la lengua hablada en todas y cada una de las regiones del país tanto en el espacio rural como en el urbano; una lengua desgeograficada.

Macunaíma coincide con los textos de Güiraldes, Rivera y Gallegos en su visión crítica del espacio urbano. La temporada que el protagonista habita en São Paulo le da la oportunidad a Andrade de explicar desde los ojos de un aborigen los avances de la civilización en el Brasil. En esa carta a la barbarie desde la civilización que es la "Carta pras icamiabas", Macunaíma -entonces "Imperador do Mato Virgem"- entrega al lector una visión poco halagüeña del espacio citadino al que resume no sólo como un "grandioso país de doenças e insetos por cuidar" (ANDRADE, 1988, p. 82), sino un lugar donde se respiraba una atmósfera de imitación y sobrevaloración de los modelos extranjeros que tanto Güiraldes como Rivera y Gallegos condenan también en sus obras. Andrade llega, incluso, a afirmar con sorna por boca de Macunaíma que "em breve seremos novamente uma colônia da Inglaterra ou da América do Norte" (ANDRADE, 1988, p. 82). En Macunaíma, a diferencia de los textos de los autores aludidos arriba, esta desconfianza hacia la importación de lo extranjero no redunda en un regreso a la tierra que se concibe como el repositorio de lo nacional; es decir de la identidad. En Andrade no hay posibilidad de esa reconciliación con la patria a través de la naturaleza que acontece en la vida de Raucho, Arturo Cova y Santos Luzardo. No hay por ende, la posibilidad de una resolución al problema de la identidad. Hay, al contrario, la certidumbre del cuestionamiento. Macunaíma decide dejar de existir porque no encuentra un sentido a su existencia. Desinteresado ante un nuevo extravío del muiraquitã, se va al cielo no sin antes afirmar que "este mundo não tem jeito mais” (ANDRADE, 1988, p. 164). Más que interpretar el final de Macunaíma como profundamente desalentador -tal y como Bosi lo entiende- propongo leerlo como la cristalización de la crítica de Andrade a todo un proyecto literario y político basado en la esencialidad telúrica de la identidad americana presente, por ejemplo, en Raucho, La vorágine y Doña Bárbara que había nacido a principios del siglo XIX en los textos 
de Humboldt. ${ }^{46}$ De hecho, la anécdota que cierra Macunaíma -el loro a quien Macunaíma había hecho aprenderse su historia la relata a un Mário de Andrade ficcionalizado- proviene de una anécdota proveniente de los escritos de Humboldt (1819): “à l'époque de notre voyage, on montroit à Maypures, et ce fait est assez digne de remarque, un vieux perroquet dont les habitans disent 'qu'on ne comprend pas ce qu'il dit, parce qu'il parle la langue des Aturès"' (p. 599).

\section{REFERENCIAS BIBLIOGRÁFICAS}

ANDRADE, Mário de. Macunaíma o herói sem nenhum caráter (coord.: Telê Porto Ancona Lopez). Brasilia: Archivos, 1988.

AZEVEDO, Aluísio de. O cortiço. São Paulo: Martins, 1972.

BOSI, Alfredo. Situação de Macunaíma. In: ANDRADE, Mário de. Macunaíma o herói sem nenhum caráter (coord.: Telê Porto Ancona Lopez). Brasilia: Archivos, 1988.

CAMBACERES, Eugenio. Sin rumbo. Buenos Aires: Centro Editor de América Latina, 1968.

CANDIDO, Antonio. O discurso e a cidade. São Paulo: Duas Cidades, 1993.

CAVALCANTI PROENÇA, M. Roteiro de Macunaíma. Río de Janeiro: Civilização Brasileira, 1969.

DÍAZ RODRÍGUEZ, Manuel. Narrativa y ensayo. Caracas: Ayacucho, 1982.

FRENCH, Jennifer L. Nature, Neo-Colonialism, and the Spanish American Regional Writers. Hanover; Londres: Darthmouth College Press, 2005.

GALLEGOS, Rómulo. Doña Bárbara. Madrid: Cátedra, 2004.

GANDAVO, Pero de Magalhães. Tratado da Terra do Brasil. São Paulo: Itatiaia, 1980.

GOIC, Cedomil. Historia y crítica de la literatura hispanoamericana. Barcelona: Crítica, 1991.

GÜIRALDES, Ricardo. Raucho. Buenos Aires: Centro Editor de América Latina, 1968.

HALPERIN DONGHI, Tulio. Historia contemporánea de América Latina. Madrid: Alianza, 1990.

${ }^{46}$ Como bien afirma Fernando J. Rosenberg, "Mário’s suspiciousness is directed toward the Eurocentric peripheral intellectual who returns from the metropolis as a completion of a Bildung to rediscover faith in the native land" (2006, p. 89). 
HUMBOLDT, Alejandro de. Voyage aux régions équinoxiales du nouveau continent: Relation historique. París: Imprimerie de J. Smith, 1819, tomo II.

LANIERI, Morena Carla. La decadencia del patriciado criollo en Sangre patricia. Actas de la AISPI XXII, p. 267-278, 2004.

LAPOLLA SWIER, Patricia. Hybrid Nations: Gender Troping and The Emergence of Bigendered Subjects in Latin American Narrative. Madison; Teaneck: Fairleigh Dickinson UP, 2009.

MADUREIRA, Luís. Cannibal Modernities: Postcoloniality and the Avant-garde in Caribbean and Brazilian Literature. Charlottesville; Londres: University of Virginia, 2005.

MARTÍ, José. Nuestra América. Barcelona: LinKgua, 2008.

MARTIUS, Carl von. Como se deve escrever a História do Brasil. Revista do Instituto Histórico e Geográfico Brasileiro, n. 6, p. 389-411, 1844.

MILLIET, Sérgio. O poeta Mário de Andrade. Revista do Arquivo Municipal, n. 106, p. 55$-68,1945$.

MONTALDO, Graciela. De pronto, el campo: literatura argentina y tradición rural. Rosario: Beatriz Viterbo, 1993.

PACHÓN FARÍAS, Hilda Soledad. Los intelectuales colombianos en los años veinte: el caso de José Eustasio Rivera. Bogotá: Colcultura, 1993.

PERA, Cristóbal. Modernistas en París: el mito de París en la prosa modernista hispanoamericana. Berlín: Peter Lang, 1997.

PRADO, Paulo. Retrato do Brasil: ensaio sobre a tristeza brasileira. Río de Janeiro: José Olympio, 1962.

RAMA, Ángel. La novela en América Latina: panoramas 1920-1980. Bogotá: Colcultura, 1982.

RANGEL, Alberto. Inferno verde: cenas e cenários do Amazonas. Tours: Arrault, 1927.

RANGEL, Alberto. Rumos e perspectivas. São Paulo: Companhia Editora Nacional, 1934.

RIVERA, José Eustasio. La vorágine. Madrid: Cátedra, 2006.

RIVERA-BARNES, Beatriz; HOEG, Jerry. Reading and Writing the Latin American Landscape. Nueva York: Palgrave; Macmillan, 2009.

RODÓ, José Enrique. Ariel. Barcelona: LinKgua, 2008.

ROSENBERG, Fernando J. The Avant-garde and Geopolitics in Latin America. Pittsburgh: University of Pittsburgh, 2006. 


$$
138 \text { - Remate de Males } 36.1
$$

SARMIENTO, Domingo Faustino. Facundo o civilización y barbarie en las pampas argentinas. Buenos Aires: Sopena, 1952.

SILVA, José Asunción. De sobremesa. Madrid: Hiperión, 2003.

SOMMER, Doris. Foundational Fictions: the National Romances of Latin America. Berkeley: University of California, 1991.

THOMAS D., Eduardo. La vorágine: el marco narrativo y el retorno del héroe. Revista Chilena de Literatura, n. 37, p. 97-104, 1991.

TIEMPO, César. Cartas inéditas de Horacio Quiroga. Montevideo: Biblioteca Nacional, 1970.

VALLES CALATRAVA, José R. Teoría de la narrativa: una perspectiva sistemática. Madrid: Iberoamericana, 2008. 